\title{
実地形モデル（湾内地形）における多方向不規則波の 波浪変形特性
}

\section{1. まえがき}

港湾構造物（人工島，防波堤等）の設計においては, 構造物周辺海域の波浪変形特性を把握することが必要で ある. 波浪変形を検討する際には数値解析のみでなく必 要に応じて水理模型実験を実施するが, 多方向不規則波 を用いた水理模型実験, 特に, 実地形モデル（一様勾配 の斜面など以外の複雑な地形のモデル）を対象とした実 験は，実施検討例がわずかしか見られない（高山ら， 1990).

また，波浪変形における入射波の多方向性の影響は， 対象とする海域モデル（地形の違い，海域内の構造物の 有無）によって異なる傾向を示すと思われる。

本研究では, 水深, 汀線が複雑に変化する実地形モデ ルを対象として，多方向不規則波，単一方向不規則波を 用いた水理模型実験を実施し，波浪変形，海浜流に及浪 す入射波の多方向性の影響を検討する，さらに，同一の 実地形に防波堤を設置したモデルを対象とし，波の回折 現象が支配的となる波浪場においての入射波の多方向性 の影響についても，併せて検討する。

\section{2. 実験の内容}

\section{（1）実験設備，模型}

地形モデル設置図を図一1に示す。

平面水槽内には 40 枚の造波板から成る多方向不規則 波造波装置（全長 $12.0 \mathrm{~m}$ ) が設置されて扔り，造波装置 前面より岸方向に約 $10 \mathrm{~m}$ の地点から $12.0 \mathrm{~m} \times 17.6 \mathrm{~m}$ の範囲に地形モデルを設置した。また，入射波が地形モ デルの設置位置に到達するまでにエネルギーが拡散する ことを防止するため，造波装置の両端から岸方向に向か つて導波板を設置した。防波堤モデルは图一1に示す様 に，地形変化開始部付近に造波装置と平行に長さ $4.5 \mathrm{~m}$ もしくは $3.0 \mathrm{~m}$ のものを設置した.

\section{（2）実験条件および実験方法}

本研究で用いた実験波を表一1 亿示す，単一方向不規 則波（ケース 2，4，6）とそれに波高，周期の対応する多

* 正会員 工修 関西電力 (株) 総合技術研究所

** 正会員 工博 京都大学教授 工学部土木工学科
目見田 哲*・酒 井哲 郎**

方向不規則波（ケース 1，3，5）を用い，実験波の周波数 スペクトルは Bretschneider一光易型，方向関数は光易 型を目標とし，主波向は造波装置と垂直方向とした。多 方向不規則波の造波信号はエネルギー等分割のダブルサ ンメーション法により周波数 1,024 個, 波向き 91 個の成 分波を合成して計算した。実験波の検定については，水 槽内に地形モデルを設置した状態で実施し，図一1に示 す波高計アレイ設置位置 (各々, 地形変化開始部付近, 防波堤先端部付近に設置）において，目標の波浪条件が ほぼ得られていることをべイズ型モデル（橋本，1987） を用いた解析によって確認した。

実験では，容量式波高計により波高，方向スペクトル を, 電磁流速計により海浜流の流速（水深の半分の深さ での流速）を計測した。なお, 計測時間は約 5 分, サン プリングタイムは $0.02 \mathrm{sec}$ 間隔とした。

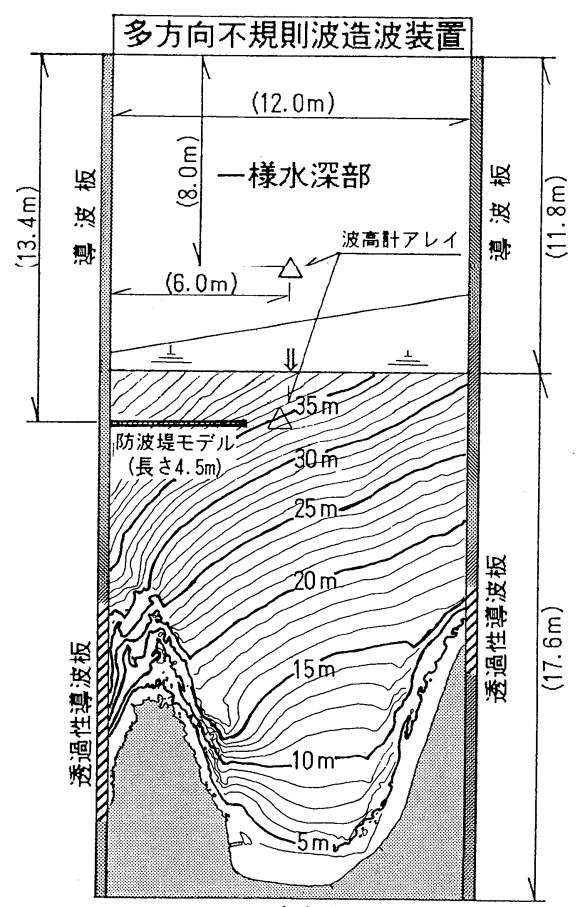

（）内は模型寸法

図一1地形モデル設置図 
表一1 実験波一覧表

\begin{tabular}{|c|c|c|c|c|c|c|}
\hline & ケース 1 & ケース 2 & ケース 3 & ケース 4 & ケース 5 & ケース 6 \\
\hline 波の種類 & $\begin{array}{l}\text { 多方向 } \\
\text { 不規則波 }\end{array}$ & $\begin{array}{l}\text { 単一方向 } \\
\text { 規則波 }\end{array}$ & $\begin{array}{l}\text { 多方向 } \\
\text { 規則波 }\end{array}$ & $\begin{array}{l}\text { 単一方向 } \\
\text { 不規則波 }\end{array}$ & $\begin{array}{l}\text { 多方向 } \\
\text { 規則波 }\end{array}$ & $\begin{array}{l}\text { 単一方向 } \\
\text { 不規則波 }\end{array}$ \\
\hline$S_{\max }$ & 25 & $\infty$ & 25 & $\infty$ & 25 & $\infty$ \\
\hline $\begin{array}{l}\text { 有義波高 } \\
\text { (入射波高) }\end{array}$ & \multicolumn{2}{|c|}{$4.80 \mathrm{~cm}$} & \multicolumn{2}{|c|}{$5.44 \mathrm{~cm}$} & \multicolumn{2}{|c|}{$6.40 \mathrm{~cm}$} \\
\hline 有義波周期 & \multicolumn{2}{|c|}{$0.98 \mathrm{sec}$} & \multicolumn{2}{|c|}{$1.39 \mathrm{sec}$} & \multicolumn{2}{|c|}{$1.39 \mathrm{sec}$} \\
\hline
\end{tabular}

（表中， $S_{\max }$ は方向集中度パラメー夕を示す）

\section{3. 実 験 結 果}

\section{（1）防波堤なしのモデル}

a ) 波高分布の特性 ケース $1 \sim 4$ の波高比分布図 (各計測ポイントの波高/入射波高, 入射波高は表一 1 参 照）を図一2および図一 3 に示す。

湾内の波高比分布を比較すると，いずれのケースにお いても等波高比線が岬沿いに密に分布し，湾中心にむか って波高が増加する分布形状を示す。

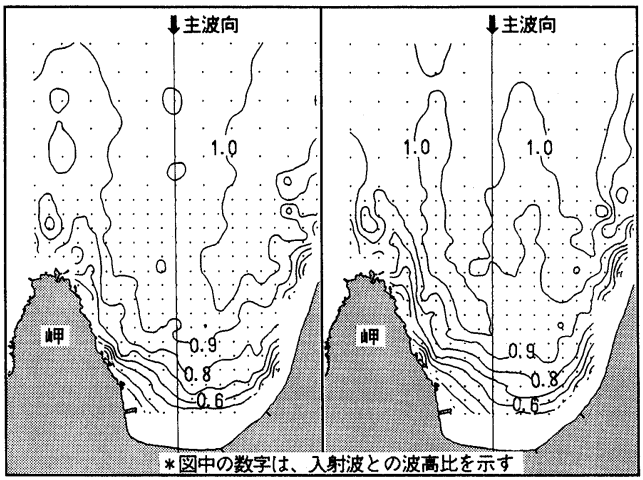

図一2 波高比分布図（防波堤モデルなし） （左図；ケース 1 ，右図；ケース 2 ）

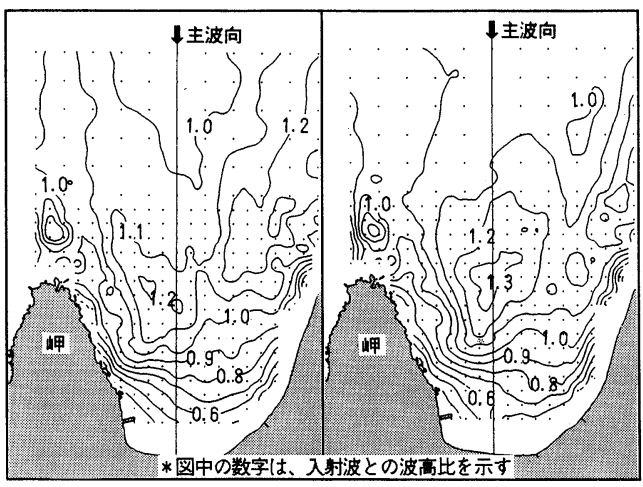

図一3 波高比分布図（防波堤モデルなし） （左図；ケース 3 ，右図；ケース 4)
多方向不規則波 $\left(S_{\text {max }}=25\right)$ のケースと波高, 周期の対 応する単一方向不規則波のケースでの波高比を比較する と両者の值はほぼ一致している。一例として, ケース 3 , 4 の波高比の比率分布図を図-4 亿示すが，湾全体にわ たって波高比の比率は 1 に近い值を示す。

多方向不規則波のケースと単一方向不規則波のケース での違いを詳細に検討すると，単一方向不規則波のケー スのなかで，波高が湾中央にむかって大きく増加するケ 一ス 4, 6 については, 対応する多方向不規則波のケー ス 3 ，5 において同程度の波高増加がみられず，結果的 に湾中央の海域においては多方向不規則波のケース 3 , 5 のほうが波高が低くなる．これは入射波の多方向性の 違いに起因した現象であると思われる。

b) 海浜流場の特性 多方向不規則波 $\left(S_{\max }=25\right)$ のケ 一スと単一方向不規則波のケースでの海浜流を比較する ため，ケース $3 ， 4$ について海浜流の流速べクトル図を

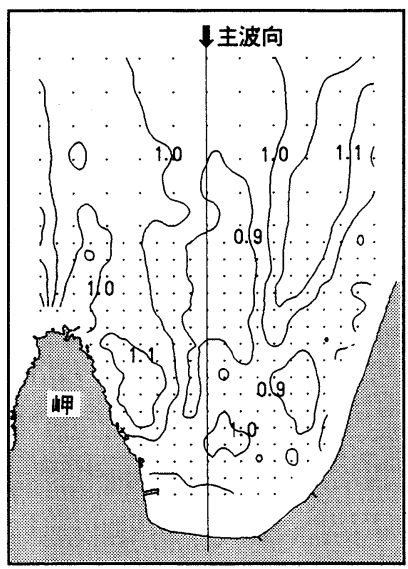

図一4 波高の比率分布図（防波堤モデルなし） (ケース 3 /ケース 4)

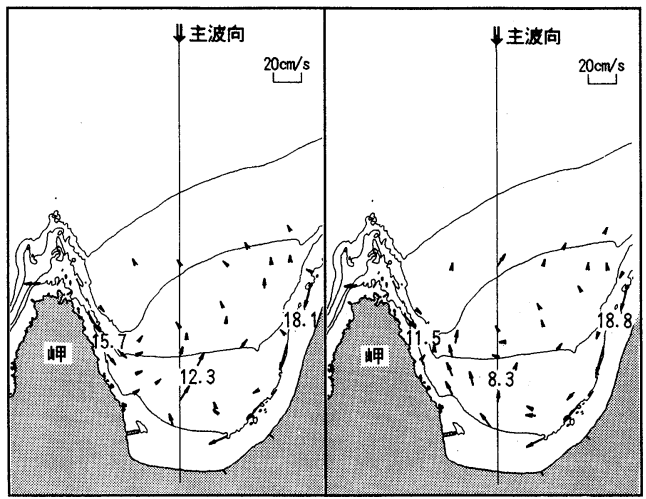

図一5 海浜流の流速ベクトル図（防波堤モデルなし） （左図；ケース 3 ，右図；ケース 4) 
図一5に示す.両ケースでの海浜流場を比較すると, 岬先 端から湾奥へ向かう速い流れ, 逆のサイドから海岸線に 沿って湾奥へ向かう速い流れ，および 2 つの流れが合流 した後に沖へ向かう流れがともに見られ，定性的な差は ない.

同様にケース 1 と 2 およびケース 5 と 6 を比較した際 にも定性的な差は見られなかった。

c) 方向スペクトルの特性 多方向不規則波 $\left(S_{\max }=\right.$ 25）のケースと単一方向不規則波のケースでの主波向を 比較するため, ケース 3,4 について, 湾内の数ポイン トにおける主波向ベクトル図を図一6に示す。両ケース を比較すると，全海域にわたって主波向がほぼ同一方向 となる．陸に接近するに従い両ケースに若干の違いがみ られ，ケース 3 における主波向の方が等深線に垂直な方 向に近づく傾向が見られる．これは多方向不規則波のケ 一ス 3 には多くの方向の成分波が含まれていることを考 慮すれば妥当な結果といえる。 また，ケース 1 と 2 , ケ 一ス 5 と 6 を比較した際にも同様の傾向が見られた。

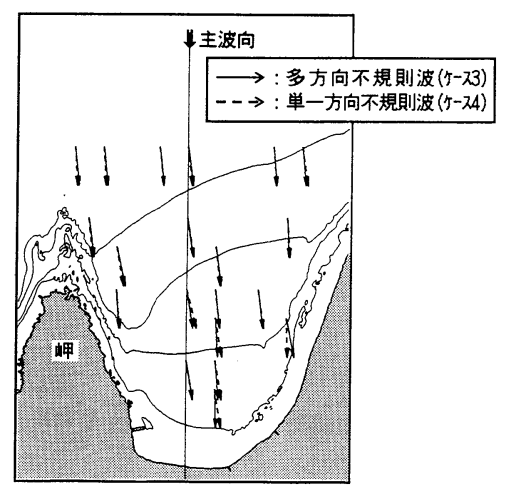

図一6 主波向ベクトル図（防波堤モデルなし）

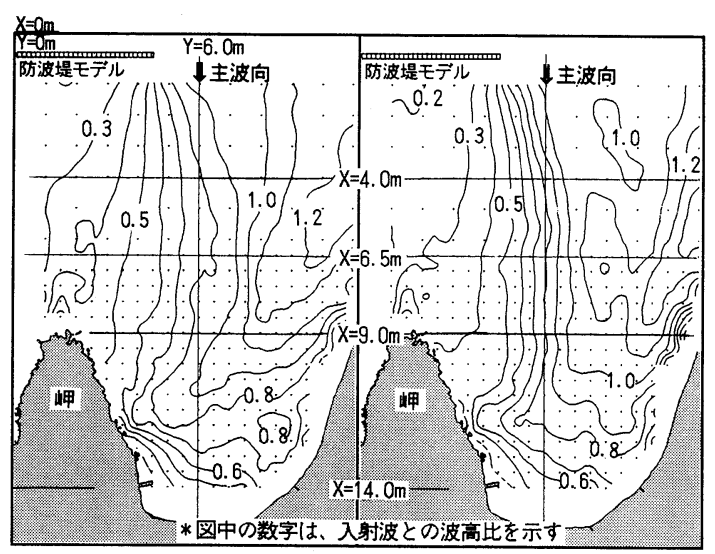

図一7 波高比分布図(防波堤モデル； $4.5 \mathrm{~m}$ ) （左図；ケース 3 , 右図; ケース 4 )

\section{（2）防波堤設置モデル（長さ $4.5 \mathrm{~m}$ )}

前節で検討した防波堤なしのモデルにおいては, 多方 向不規則波 $\left(S_{\max }=25\right)$ と単一方向不規則波のケースを比 較した結果，入射波の多方向性の違いによる影響はほと んど見られなかった，次に，多方向不規則波 $\left(S_{\max }=25\right)$ と単一方向不規則波のケースの違いがあらわれると予想 できる海域モデルとして, 同一の実地形に防波堤（長さ $4.5 \mathrm{~m}$ ) を設置したモデルを対象とし, 同一の実験波を用 いて波高, 海浜流の流速, 方向スペクトルを計測した。

a) 波高分布の特性 ケース 3,4 の波高比分布図(各 計測ポイントの波高／入射波高）を図一7に示す.

ケース 3，40波高比を比較すると, 波の回折現象が 発生する防波堤背後の海域においては, 多方向不規則波 のケース 3 の方が波高比が大きくなる。これは入射波の 多方向性の違いに起因した現象である。次に，ケース 3 と 4 の波高比の比率分布図を図-8 に示す. 防波堤背後 の海域においてはケース 3 での波高増加が見られるが, 他の海域においては, 防波堤なしのモデルの際と同様, 波高比の比率は 1 に近い值を示す。また，ケース 1 と 2 およびケース 5 と 6 を比較した際にも同様の傾向が見ら れた。

b ）海浜流場の特性 ケース 3,4 についての海浜流 の流速ベクトル図を図一 9 に示す．両ケースとも湾に沿 った海浜流が確認できるが，ケース 4 において海浜流の 顕著な発達がみられる．特に，ケース 4 で発生している 湾奥から湾沿いに岬の先端方向へむかう速い流れは，ケ ース 3 においてはみられない。これは，多方向不規則波 のケース 3 においては，入射波の防波堤背後への回折現

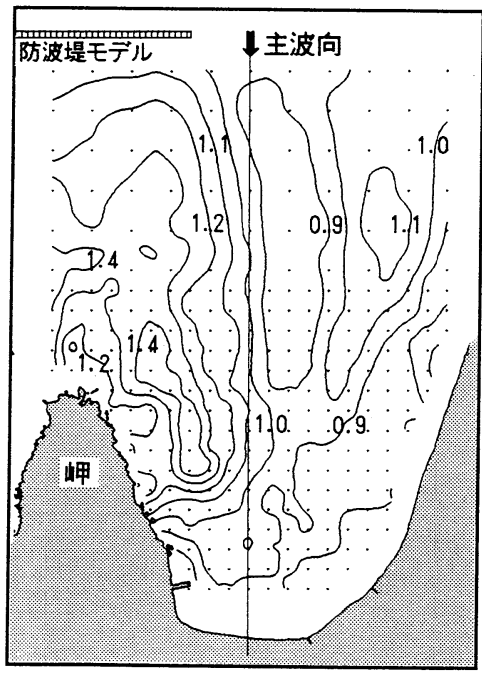

図一8 波高の比率分布図（防波堤モデル； $4.5 \mathrm{~m}$ ) (ケース $3 /$ ケース 4) 


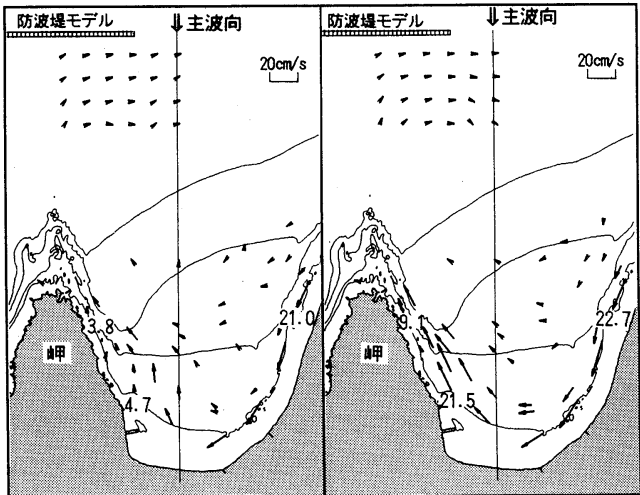

図一9 海浜流の流速ベクトル図（防波堤； $4.5 \mathrm{~m}$ ) （左図；ケース 3 , 右図；ケース 4)

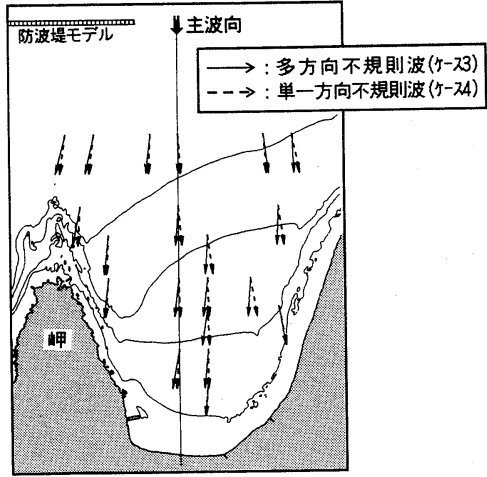

図一10 主波向ベクトル図（防波堤モデル；4.5 m）

象が顕著となり湾に沿った海浜流の発達が弱まったため と思われる。

また，ケース 1 と 2 抢よびケース 5 と 6 を比較した際 にも同様の傾向が見られた。

c) 方向スペクトルの特性 ケース 3,4 について, 湾 内の数ポイントにおける主波向ベクトル図を図一 10 に 示す. 両ケースを比較すると, 入射波の多方向性の違い より, ケース 3 において, 防波堤背後付近での主波向が 防波堤側に傾斜する，また，岸に接近するに従い，ケー ス 3 における主波向が等深線に垂直な方向に近くなって いく傾向が確認できる.また，ケース 1 と 2 およびケー ス 5 と 6 を比較した際にも同様の傾向が見られた.

\section{(3) 防波堤設置モデル（長さ $3.0 \mathrm{~m}$ )}

前節で検討した防波堤設置モデル $(4.5 \mathrm{~m})$ における検 討結果をさらに明確に確認するため, 防波堤の長さを短 くしたモデル (防波堤の長さ； $3.0 \mathrm{~m}$ ) を対象とし, 同一 の実験波を用いて波高，海浜流の流速を計測した。

ケース $3 ， 4$ について，波高比分布図を図一11 に，海 浜流の流速べクトル図を図一 12 に示す.ケース 3,4 を 比較すると, 防波堤の長さが $4.5 \mathrm{~m}$ の際と同様に, 防波

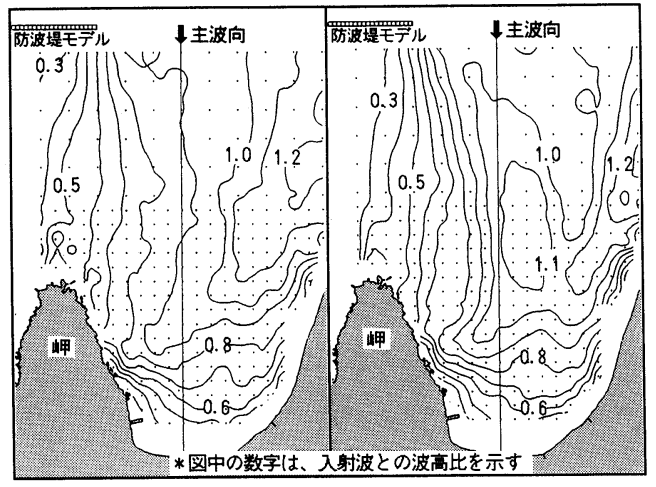

図一11 波高比分布図（防波堤モデル；3.0 m) (左図；ケース 3 ，右図；ケース 4)

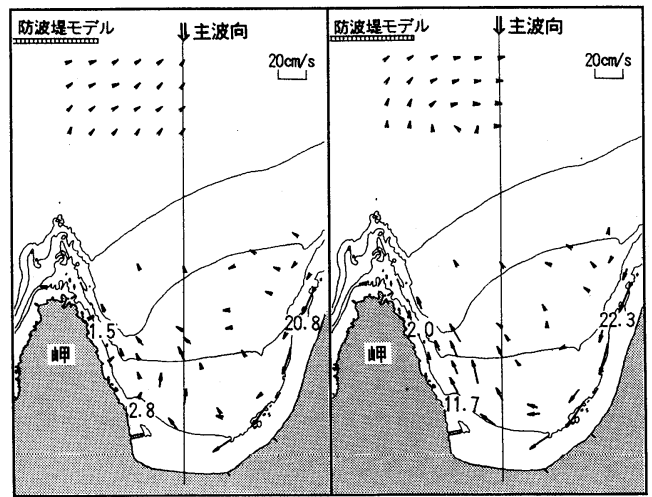

図一12 海浜流の流速ベクトル図（防波堤； $3.0 \mathrm{~m}$ ) (左図；ケース 3 ，右図；ケース 4 )

堤背後の波高の増加, 呷に沿った海浜流の顕著な発達な どの入射波の多方向性による影響が見られる。

さらに, 防波堤の長さを短くし, 背後の回折領域を狭 くしたことによって，防波堤背後の波高増加の海域が狭 くなったこと, 岬に沿った海浜流の発達の度合いが弱く なったことから，前節で示したところの入射波の多方向 性と防波堤背後の波高増加, 海浜流の発達との関連性が 確認できたといえる.

\section{4. 考察}

今回，対象とした防波堤設置モデル（長さ $4.5 \mathrm{~m}$ )の波 浪変形については類似の実験の実施例が少ないため, 数 值解析（エネルギー平衡方程式）を実施して波高分布を 算定し，実験結果と比較検討した。

本研究では, 計算対象領域は図一1 に示す防波堤設置 位置より陸側の海域とし, 空間格子間隔は $16 \mathrm{~cm}$ とし た. 

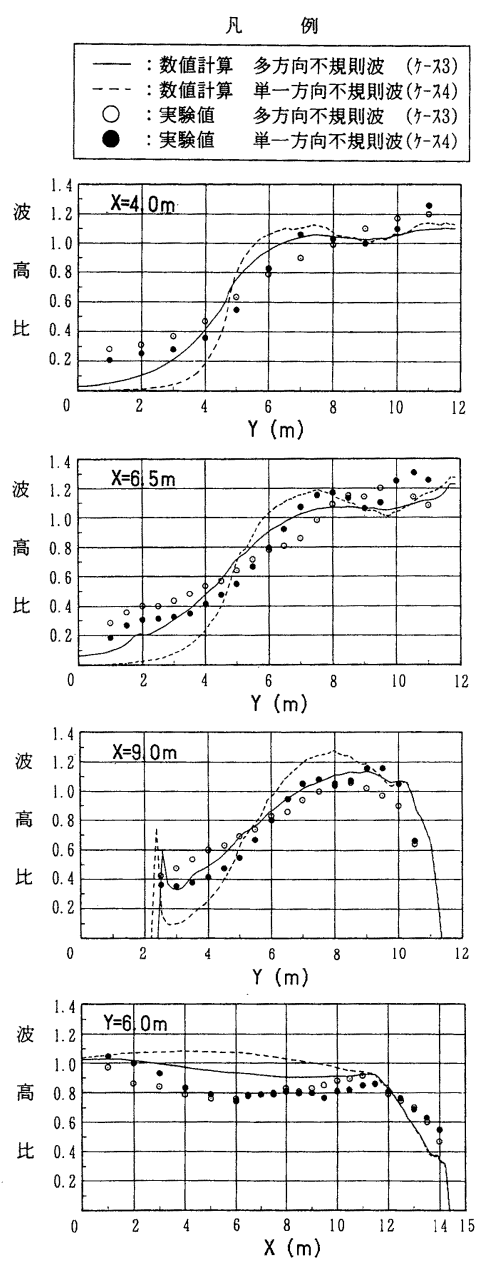

図-13 測線上の波高比変化

また, 境界条件としては, 導波板の反射率を 1.0 , 透過 性導波板, 陸地部の反射率を 0 とした。 入射波の成分波 分割数は, エネルギー等分割のダブルサンメーション法 により, 周波数 10 分割 $\times$ 波向 45 分割の合計 450 成分と し，砕波モデルとしては高山モデル（高山ら，1991）を 用いた. ケース 3,4 の数值解析結果について, 図一7に 示した 4 つの代表測線上 $(X=4.0 \mathrm{~m}, 6.5 \mathrm{~m}, 9.0 \mathrm{~m}, Y=$
$6.0 \mathrm{~m} ）$ の波高比分布を実験値とともに図一 13 に示す.

これによると, エネルギー平衡方程式による数值解析 值は，防波堤背後の海域 $(X=4.0 \mathrm{~m}, 6.5 \mathrm{~m}$ の測線上で $Y$ の值が小さい海域）においては，波高をやや過小評価 する傾向が見られるものの，その他の海域においては実 験值とよく一致する傾向が見られる。防波堤背後の海域 の結果については, エネルギー平衡方程式では回折現象 が原理的に考慮されていないことからも予想できる結果 といえる.

\section{5. あとがき}

今後も, 多種類の地形モデルについて水理模型実験を 実施し, 多方向不規則波の挙動を単一方向不規則波のも のと比較検討していくことは重要である. 特に, 今回の 地形モデルとは異なる結果があらわれる可能性のあるモ デル（湾内地形でないモデル等）についての検討が必要 といえる.

最後に，方向スペクトル関連の実験手法について貴重 なアドバイスを頂いた(財)電力中央研究所 池野正明氏 に謝意を表します。また，計測にあたっては(株)日本工 業試験所 内西 博氏, 数値解析にあたっては(株)二ュ ージェック 殿最浩司氏の協力を得ました。ここに記し て謝意を表します。

\section{参 考 文 献}

池野正明・鹿島遼一・松山昌史・楜山 勉・洼 泰浩 (1993)：人 工島式発電所背後の波浪場・海浜流場に関する実験的研究, 海岸工学論文集, 第 40 巻, pp. 621-625.

池野正明 - 鹿島遼一・鵜飼亮行・清水玩三・秋葉 徹 - 寉 泰浩 (1994)：多方向不規則波浪場計算法の人工島背後海域への 適合性比較, 海岸工学論文集, 第 41 巻, pp. 121-125.

合田良実・鈴木康正 (1975)：光易型方向スペクトルによる不規 則波の届折・回折計算, 港湾技研資料, No. $230,45 \mathrm{p}$.

高山知司・池田直太・小杉宜史 (1990)：多方向不規則波を用い た波浪変形実験，海岸工学論文集，第 37 巻，pp. 155-159.

高山知司・池田直太・平石哲也 (1991)：研波および反射を考慮 した波浪变形計算，港研報告，第 30 巻，第 1号，pp. 21-67. 橋本典明 (1987): ベイズ型モデルを用いた方向スペクトルの推 定, 港研報告, 第 26 巻, 第 2 号, pp. 97-125. 